\title{
Advanced practices for care management: reflections on the Brazilian Nursing
}

\author{
Práticas avançadas para a gestão do cuidado: reflexão emergente à enfermagem brasileira \\ Prácticas avanzadas para la gestión del cuidado: reflexión emergente a la enfermería brasileña
}

\section{João Lucas Campos de Oliveira',", ${ }^{1,}$ Beatriz Rosana Gonçalves de Oliveira Toso", Laura Misue Matsuda' \\ ' Universidade Estadual de Maringá. Maringá, Paraná, Brazil. \\ "Universidade Estadual do Oeste do Paraná. Cascavel, Paraná, Brazil.}

\begin{abstract}
How to cite this article:
Oliveira JLC, Toso BRGO, Matsuda LM. Advanced practices for care management: reflections on the Brazilian Nursing. Rev Bras Enferm [Internet]. 2018;71(4):2060-5. DOI: http://dx.doi.org/10.1590/0034-7167-2017-0115
\end{abstract}

Submission: 03-21-2017 Approval: 06-26-2017

\begin{abstract}
Objective: to explain about the Advanced Nursing Practice and to discuss the possibilities of the Advanced Practice for the management of nursing care in Brazil. Method: this is a theoretical-reflexive trial, based on the international literature on advanced practices in nursing and analysis relevant to the profession and to the Brazilian context. Results: the object of the study was described in the following driving axes: Advanced Practice Nurse: international examples and Brazilian reality; Reflections on the care management by the Advanced Practice Nurse in Brazil. Autonomy, qualified training, leadership and performance based on scientific evidences as the foundation of the best care management by the Advanced Nursing Practice, stand out. Final considerations: while early and challenging, the work of Brazilian nursing towards advanced professional practice seems to be interesting, since the possibilities of managing the care of this modality of nurses' performance are evident.

Descriptors: Advanced Nursing Practice; Nurse Women and Nurse Men; Management; Health Management; Management of Professional Practice.
\end{abstract}

\section{RESUMO}

Objetivo: explanar acerca da Prática Avançada em enfermagem e discorrer sobre as possibilidades da Prática Avançada para a gestão do cuidado de enfermagem no Brasil. Método: ensaio teórico-reflexivo, embasado na literatura internacional sobre práticas avançadas na enfermagem e análise pertinente à profissão ao contexto brasileiro. Resultados: o objeto do estudo foi descrito nos seguintes eixos condutores: Enfermeiro de Prática Avançada: exemplos internacionais e realidade brasileira e; Reflexões sobre gestão do cuidado pelo enfermeiro de Prática Avançada no Brasil. Destaca-se a autonomia, a formação qualificada, a liderança e a atuação baseada em evidências científicas como alicerces da melhor gestão do cuidado pela Prática Avançada de enfermagem. Considerações finais: apesar de embrionária e desafiadora, a empreitada da enfermagem brasileira rumo à prática profissional avançada parece ser interessante, pois as possibilidades de gestão do cuidado desta modalidade de atuação do enfermeiro são evidentes.

Descritores: Prática Avançada de Enfermagem; Enfermeiras e Enfermeiros; Gerência; Gestão em Saúde; Gerenciamento da Prática Profissional.

\section{RESUMEN}

Objetivo: explicar sobre la Práctica Avanzada en enfermería y discurrir sobre las posibilidades de la Práctica Avanzada para la gestión del cuidado de enfermería en Brasil. Método: ensayo teórico-reflexivo, basado en la literatura internacional sobre prácticas avanzadas en la enfermería y análisis pertinente a la profesión al contexto brasileño. Resultados: el objeto del estudio fue descrito en los siguientes ejes conductores: Enfermero de Práctica Avanzada: ejemplos internacionales y la realidad brasileña; Reflexiones sobre gestión del cuidado por el enfermero de Práctica Avanzada en Brasil. Se destaca la autonomía, la formación cualificada, el liderazgo y la actuación basada en evidencias científicas como cimientos de la mejor gestión del cuidado por la Práctica Avanzada de enfermería. Consideraciones finales: a pesar de embrionaria y desafiante, la tarea de la 
enfermería brasileña hacia la práctica profesional avanzada parece ser interesante, pues las posibilidades de gestión del cuidado de esta modalidad de actuación del enfermero son evidentes.

Descriptores: Práctica Avanzada de Enfermería; Enfermeras y Enfermeros; Gerencia; Gestión de la salud; Gestión de la Práctica Profesional.

CORRESPNDING AUTHORＪoão Lucas Campos de OliveiraＥ-mail: enfjoaolcampos@yahoo.com.br

\section{INTRODUCTION}

The constant social and epidemiological changes impose on the health sector the need to continually elaborate strategies that enable responses to the demands of care that are not infrequently complex. In these terms, the responsibility of the human resources in this peculiar sector of production is evident, since the health professionals are in charge of operating actions aimed at meeting the needs of customers.

The Health Care needs - although they differ according to the socioeconomic realities of each context - deserve a lot of attention, as is the case in Latin American and Caribbean countries, where the difficulty of access to services by users, low resolution and bad quality of assistance are problems that need to be managed ${ }^{(1)}$. For these and other reasons, the health care team needs to be qualified to precisely meet the demands of work in a scenario full of adversity, especially the lack of human resources and supplies (of wide technological variability) needed for the assistance ${ }^{(1-2)}$.

Nursing professionals are essential in promoting direct assistance at the different levels of care and cycles in the life of the human being, since this working class has, as an elementary product of their performance, the care ${ }^{(1,3)}$. Nevertheless, in the nurses' field of work, the work goes beyond direct care, because this professional must apprehend knowledge, skills and expertise that culminate in the management of the assistance or management of care here understood as indirect care, that is, systematic actions that enable resources and strategies for conscious care, aiming at their best quality ${ }^{(3)}$.

It should be emphasized that the management work by nurses should not merely restate the traditional hierarchical structure of the nursing team or strengthen the pointless point of view between management and assistance, since it makes the understanding of the own identity of nurses difficult and sharpens possible problems of relationship with the team ${ }^{(3-4)}$. In this way, being a fundamental part of the whole work of the nurse, the management exercised by this professional needs to subsidize the management of several resources necessary for the assistance like mobilizing work team conduct; planning; organizing; and evaluating actions of interest in nursing care $\mathrm{e}^{(5-6)}$.

Although important, the management work by nurses can be hampered by several factors, such as the already mentioned dichotomy between management and assistance ${ }^{(3-4,6)}$; biomedical models of Health Care; lack of resources; of decisions little or no shared among the members who produce the care ${ }^{(7)}$. In this regard, changes in both work organization and professional nurse mapping have been recommended in order to leverage the solution of individuals and communities' health problems, including due to their recognized ability to manage care ${ }^{(1-2)}$.

One possibility listed as favorable to the autonomy of nurses for decision-making in favor of improvements in health conditions is the Advanced Nursing Practice ${ }^{(8-9)}$, which consists of a formal level of professional qualification corresponding to the specialized knowledge base, with complex decision-making ability, clinical skills for the Advanced Practice in their area of expertise, whose characteristics are shaped by the context or country in which they are authorized to $\mathrm{act}^{(9)}$. In parallel, the term referred to the qualified professional has been translated into Portuguese as Advanced Practice Nurse (EPA) ${ }^{(1)}$.

Considering that the topic Advanced Practices in the Brazilian nursing scene is pulsed, but incipient ${ }^{(1,8)}$, and that outlines more clearly on the possibilities for the management of care in this modality of professional performance, can contribute greatly to the improvement of the quality of assistance and also, the nurses' own work practice. This study focused on the following questions: How does the Advanced Nursing Practice in different national contexts present? What are your outlooks on care management in Brazil? To answer them, this study aimed to explain about the Advanced Nursing Practice and discuss the possibilities of the Advanced Practice for the management of nursing care in Brazil.

\section{METHOD}

This is a theoretical and reflective trial carried out from studies and debates relevant to the discipline of Tecnologias Gerenciais em Saúde e Enfermagem (Management Technologies in Health and Nursing) of the Post-Graduate Program in Nursing, at Doctorate level, in the State University of Maringá. The discipline was developed between August and December of 2016, in a dialogical way on themes emerging to the management of the nursing care, including the theme "advanced practices".

The proposed reflections were based on (mainly) the international and national literature ${ }^{(1-2,8-19)}$ related to the theme, as well as the authors' own experience in practice, in teaching, and especially in research in management/management in nursing. As it is not a systematic review of the literature, the material used was obtained mainly by indication from one of the authors, who, during the development of a post-graduate internship, completed in 2014, has focused hard on the knowledge about Advanced Nursing Practices around the world.

The presentation of the explanations and reflections to be developed will become conducting axes on the subject, coming from interpretations of the literature and also, reflective insights of the authors. These interpretations were guided by an understanding of the theme in the world context, that is, the "state of the art" of the EPA in different contexts, and directed to its reflection on the Brazilian reality. In addition, since there was no direct/applied research interaction, the need to submit the study to ethical procedures was excluded.

\section{Advanced Practice Nurse: international examples and Brazilian reality}

The term Advanced Practice emerged in the United States of America in the early 1970s and in Canada in the 1990s to 
replace "expert" notation. Originally, the EPAs of the USA were professionals with high levels of education in the areas of nursing in anesthesiology, obstetrics, clinical practice, and nurse practitioners $^{(10)}$, who commonly work in Primary Health Care and health care/management of acute and chronic diseases ${ }^{(2,9)}$.

The Advanced Nursing Practice is related to a degree of formal education, in an in-depth theoretical-practical level - usually represented by certification in Master's or Doctoral's degree - and specific in a given area of choice of the qualified nurse ${ }^{(9)}$. Thus, the dissemination of the Advanced Nursing Practice in both the USA and Canada, which occurred later, but in a very similar way, also accompanied the increased concentrations of online and/or blended learning Master's and Doctoral programs for nurses, in the USA ${ }^{(10)}$.

It is emphasized the importance given to the high level of education of the North-American EPAs, once the focus on formal education (qualification at different degrees); the direction of work based on practice-based evidence; commitment to continuing education; the certification and its revalidation of the clinical skills and abilities related to the area of performance are very serious points ${ }^{(11)}$. These factors, in essence, underpin the Advanced Nursing Practice ${ }^{(2,9-11)}$.

A study of the Advanced Nursing Practice in 12 countries found that the rising of the EPA was heavily linked to attempts by health systems and services to cater for the inadequate ratio - so-called gaps - of physicians per inhabitant ${ }^{(2)}$. In this regard, the EPA seems to have been created with a view to increase equity and access to health care, as well as the conscious use of human resources, which corresponds to the Brazilian initial experience, which tends to be related to the plan for the universal coverage - that is, access expansion - of the Pan American Health Organization (PAHO) ${ }^{(1)}$.

Regarding the implementation of the Advanced Nursing Practice in different countries, it is perceived that the EPA regulations; its range of operation; its legislative processes and the health assistance models themselves can be considered both as factors that make the viability of this professional modality easy, and also difficult ${ }^{(2)}$. France, for instance, clearly and austerely defined the limits and possibilities of EPA's action through legislative regulation ${ }^{(2)}$. Therefore, the changes to be implemented throughout the national territory for the expansion of its areas and practices are centralized ${ }^{(2)}$.

Regarding the obstacles to the operationalization of the EPA, it is known that the culture of a assistance model based on the biomedical principles of care can make it difficult for nurses to act "beyond" their traditional practice, that is, advance in the decisions related to the care plan. In this scope, international experience says that, in countries where assistance (focusing on primary care) is permeated by seamless multiprofessional practices, as in the case of Finland, the implementation of the EPA is easier, unlike where predominates the model focused on the figure of the physician, being this an obstacle to the process of deployment of the practices advanced by the nurse ${ }^{(2)}$.

Another example of the EPA's performance was in Australia, about the possibility of this professional category to prescribe medications ${ }^{(2,12)}$. In that country, there was a legislative change in 2006 for pharmacological prescription action, but by 2009 almost a third of the Australian EPAs that could undertake such activity were still awaiting license for $i^{(12)}$, possibly related to the difficulties of Advanced Practice in the context of recognition of legislation and/or of the power of medical power ${ }^{(2)}$. In addition, it is worth noting that in Australia the prescription of medicines by nurses may or may not be followed by the supervision of physicians and to prescribe medicines, an additional time of 60 to 80 hours is required in the advanced practice training program ${ }^{(2)}$.

In Canada, there is little standardization of EPA training programs both in the context of Primary Health Care (PHC) by so-called nurse practitioners, like in the hospital assistance by clinical nurse specialists, and this is a factor that makes regulation of professional practice more difficult in the different provinces of the country ${ }^{(13)}$. Still in the context of Canadian PHC, there is a great difficulty in obtaining portability of professional regulation among different jurisprudence, precisely because of the diversity of assistance models existing at this level of care ${ }^{(2,13)}$.

A recent example is the reality of Japan, which had its first Advanced Practice Nurse in 2010 ${ }^{(14)}$. The strategy, still under construction in this country, began with the referral of 12 nursing professors to know and understand the performance of the EPA, as well as to transpose the applicability of this professional model to Japan. The country's justification in seeking to disseminate the performance of the EPA seems to be based on an evident population aging, where the control of chronic diseases and the promotion of the quality of life are imperative. Japan's recent experience recommends that changes in legislation in terms of EPA's performance and its qualification need to keep pace with political undulations, and that this tends to be valued at improving access to health services, quality and safety in reduction of health costs ${ }^{(14)}$.

Regarding access to the assistance, it should be pointed out that PHC will certainly have a strategic position in the plan for universal health coverage, mentioned above, because its low concentration of technological density combined with the possibility of high resolution, intensifies the role of nurses ${ }^{(15)}$. Thus, a systematic review of the literature conducted by researchers based in England found through the analysis of 11 randomized clinical trials and 23 observational studies that nurse practitioners, one of the most widely disseminated EPA modalities, compared with physicians of the same services increased the satisfaction of the patient attending the PHC, carried out longer consultations and researched more about the health problems of the clientele ${ }^{(16)}$.

In addition to the benefits attributed to the EPA in PHC, other points reinforce its adherence in several experiences, such as: change in the demand for care, which is better managed, especially for patients with chronic diseases; reduction of health care services costs by 0.3 to $0.5 \%$ per year; promotion of careers to nurses ${ }^{(2)}$. Based on this, it is premised that this benefit scenario also contributes to the retention of EPA in the profession, satisfaction with work and; as already mentioned ${ }^{(2)}$, the supply of insufficient physicians in priority areas, such as in the assistance to acute diseases of rapid resolution.

The EPA's resolution is most likely related to its elementary characteristic of high professional qualification, since the need to disseminate specific post-graduate programs at Master level that include education, training and practical experience, as well as a national examination of certification to enable the professional to act in the field, are international recommendations of contexts that have been trying this modality for a long time, like the USA ${ }^{(17)}$. Perhaps for this reason, the initial reality of Brazil seems to be 
returning to the viability of the Advanced Nursing Practice mediated by the Professional Master's courses and also, from the formation in the residence for nurses, with later complementation to reach the Master's degree, even at a professional level ${ }^{(8)}$.

In Brazil, the official discussion about advanced practices in nursing began in November 2015 with the Brazilian Federal Nursing Board $\left(\right.$ COFEN) ${ }^{(18-19)}$. In May 2016, COFEN, together with the Coordination for the Improvement of Higher Education Personnel (CAPES), the Brazilian Nursing Association (ABEN) and the Ministry of Health, implemented this type of training and care in the country ${ }^{(19)}$.

The Brazilian proposal of EPA is structured in the axes: training of professors and multipliers by the terms of decentralized education; implementation of core curriculum for resident nurses, including the possibility of completing this post-graduate modality for the acquisition of the Professional Master's degree and; dissemination of measures that favor clinical protocols that support nurses' autonomy in their advanced performance ${ }^{(19)}$. This is because, since the beginning of the EPA discussions in Brazil, the focus has always been on increasing access to health services by the population, so that it is attended by qualified professionals and thus, provide high resolution ${ }^{(18)}$.

Although not strictly linked to the growing proposal of the EPA in Brazil, a very recent fact that may help incorporate this innovative strategy of the profession is the provision of, in addition to the Masters courses, the inclusion of the Doctorate at a professional level regulated by Decree Order nr 389 of March 23, 2017 of the Ministry of Education ${ }^{(20)}$. This resolution clearly defines as one of the objectives, to qualify qualified professionals for the practice of advanced professional practice and transforming procedures, in order to meet social, organizational or professional demands and the labor market ${ }^{(20)}$. In the context of nursing, such a purpose can mean the bridge between production and critical consumption of research in the assistance setting, a fact that is in line with EPA principles ${ }^{(11)}$.

It is evident that the Brazilian reality is still in the scope of the discussions that govern the full realization of the EPA in the country, which will certainly be accompanied by challenges to be faced. This is because, in Brazil, nursing is structured in a hierarchical way; tends to submit to the biomedical assistance model and faces serious challenges related to the training of human resources, to the example of online education that has emerged as a "possibility" to graduate nurses, besides mercantile education that is not committed to the quality of training in nursing.

It is expected that the proposal of the advanced practices in Brazil will be accompanied by due planning for its implementation and co-responsibility of interested bodies and agencies, to the example of the working class leaderships, the Ministry of Health and the training centers, including the evident relevance of the Masters in this goal, which seems to be a key point ${ }^{(8)}$. Through these partnerships, the nurse's role can, in fact, provide better health and life conditions for the population and, at the same time, contribute to their consolidation in the management of care.

\section{Reflections on care management by the Advanced Practice Nurse in Brazil}

The management work is inherent to the nurses' performance. In the context of advanced practices, this becomes more prominent because leadership, decision-making, and planning for best care are competencies that underpin $\mathrm{EPA}^{(11)}$. Although the competencies cited are necessary to the nurse's job, or not through an advanced education, the latter can mediate their greater capacity to decide on the care to be managed because Advanced Practice requires a broad and deep knowledge of a given assistance reality.

It has already been mentioned that in Brazilian, nursing management is sometimes dissociated from direct care. According to the literature ${ }^{(3-4)}$, this fact compromises the professional identity of the nurse, which can culminate in poor quality of nursing assistance. Given this and what is observed in the experiences around the world, it is perceived that the EPA has the care management as the foundation of its professional performance, even because the performance of the practice understood as "advanced" incurs the mobilization of actions essentially strategic that go beyond the repetition of tasks or bureaucratic activities, here understood as decontextualized and/or unnecessary actions, that do not have applicability in the care.

Through the high qualification in a particular area or professional expertise, the EPA does not limit its action in direct care, as it happens in the Brazilian nursing reality. The EPA management actions in Brazil, even though they may have a "management" character, because they promote planning, organization and evaluation actions, should be more seamless and innovative in order to solve problems related to the demands of their scope. That is, directed toward clinical decisions and less toward just reaching organizational goals.

The reference expressed has validity in the context of Brazilian nursing in the hospital environment, in which the attribution of exclusively management and other essentially assistance positions are clearly observed. It is not necessary here to question this reality, since this probably alleviates the excessive workload of the Brazilian nurses. However, it is known that sometimes those in management positions are not aware of the real problems of care units and, in parallel, "assistant" nurses are not interested in increasing strategic actions for improving care, assigning bureaucracy management work in the sectors ${ }^{(21)}$.

Given the above, the Advanced Nursing Practice in Brazilian hospitals could result in a clearer definition of the activities of each professional. One strategy for this would be to empower the nurses responsible for direct care to the assistance management actions of each expertise of care, and also to clearly define the work of the management of the sector - harmoniously to the assistance needs - to those in positions of coordination. In fact, it is known that this happens in the national hospital routine, however, the presence of the EPA can provide greater autonomy (mediated by specific knowledge, commitment and practice-based evidence) to decisions about managed care, which will certainly need to review the management models of hospital nursing services.

In the context of APS, a study developed in England highlights that nurse practitioners enable improvements in physical examination of users; in the choice of therapeutic plan, including medicine prescriptions; in the hypothesis and/or in the diagnostic closure of health problems; in the planning of multiprofessional activities through case management; and also, they promoted the nurse's ample leadership towards the health team ${ }^{(15)}$. Based on these data, it is evident, therefore, the 
direct relationship of the work of the EPA with the management for the best assistance, in other words, with care management.

In Brazil, as mentioned, the management exercised by the nurse may or may not be accompanied by direct management and decisions about care. Abroad, the experience of one of the authors of the study presented here indicates that the EPA is responsible for the assistance management. However, with the full differential of decision-making autonomy about actions of organization of clinical cases, including actions that, in the Brazilian context, are positioned as a medical act, as is the case of prescription medicines.

Prescription of medicines by nurses in Brazil is recognized as legal action, especially in PHC, whose practice is governed by decentralized agreements that govern its extension ${ }^{(22)}$. Although regulated, the prescription of medicines by Brazilian nurses has little legitimacy, either by the population or even by the professionals themselves ${ }^{(22)}$. It is considered that this problem is not unique to the scientific community, because the question is given by several factors, but in Brazil, this certainly occurs due to the fact that health care is strongly influenced by the biomedical model of care.

The stated problem may be another intervening factor in the implementation of the Advanced Nursing Practices in Brazil, since following the recognition of its area of specialty and scope of autonomy in the actuation, possibly the society and the professionals themselves would more easily legitimize some practices recognized as "empowerment" when directed by the nurse. Although it is frivolous and counterproductive to limit the management of care to decision-making power in the prescription of medicines, this may facilitate the therapeutic orientation of people and communities, especially in several geographic areas of Brazil whose proportion of doctors per inhabitant is more precarious, to the need to implement EPA in other national realities ${ }^{(2)}$.

It is recognized that prescribing medicines is extremely serious when it comes to patient safety management, which has been very well represented by Brazilian nursing staff(5-6). For this and other reasons, it is considered fundamental that the organs of interest to the implementation of the EPA in Brazil take excellence training as the guiding axis of the Advanced
Nursing Practice, in order that the qualified nurses can actually have their action based on the problem solving they manage, contributing solidly to the quality and safety of care.

\section{Study limitations}

Due to the type of study presented, it is prudent to say that the reflections described, to a certain extent, naive or just optimistic, can not be taken as conclusive truths, once the limitation has been placed on the impossibility of asserting, still, about any benefit or change in health status through the Advanced Nursing Practice in Brazil.

Contributions to the area of nursing, health or public policy

Despite the express limitation regarding the embryonic panorama of the advanced practices in Brazilian nursing, it is considered that the allusions presented are, in fact, valuable to the effectiveness of the EPA in Brazil; since the clear incipience on the subject among Brazilian nursing needs to be overcome. Therefore, the contribution of the study is due to its clarity and perspective for the future.

\section{FINAL CONSIDERATIONS}

Reflections on the Advanced Nursing Practices were made, with the mention of international experiences; the contextualization of the Brazilian reality and the possibilities of this modality of nurses' performance to care management in Brazil. Thus, in the national context, the EPA seems to emerge as a useful strategy for improving services and care with a focus on PHC.

Still on the national reality, the discussions that emerge confirm that the authorization of the EPA tends to the education through the Professional Master's and a parallel curricular of this modality of Post-Graduate with Residence in Nursing. Another point that may favor the Advanced Practice in Brazilian nursing is the recent possibility of the doctorate in professional level, which tends to help the conscious incorporation of the research in the means of care. In this regard, if such a strategy accompanies massive social support in the various interested and related sectors, such as the medical class, it can favor EPA autonomy with positive ramifications for users and health organizations.

\section{REFERENCES}

1. Cassiani SHB, Zug KE. Promoting the Advanced Nursing Practice role in Latin America. Rev Bras Enferm[Internet]. 2014 [cited 2017 Jan 23];67(5):673-4. Available from: http://www.scielo.br/pdf/reben/v67n5/0034-7167-reben-67-05-0677.pdf

2. Dalamaire M, Lafortune G. Nurses in advanced roles: a description and evaluation of experiences in 12 developed countries. OECD Heal Work Pap[Internet]. 2010[cited 2017 Jan 23];54(5). Available from: http://dx.doi.org/10.1787/5kmbrcfms5g7-en

3. Maziero VG, Bernardes A, Spiri WC, Gabriel CS. Building meanings about management assistance: a phenomenological study. Cienc Cuid Saude[Internet]. 2014[cited 2017 Feb 04];13(3):563-70. Available from: http://periodicos.uem.br/ojs/index.php/ CiencCuidSaude/article/view/23245/pdf_342

4. Lucca TRS, Vannuchi MTO, Garanhani ML, Carvalho BG, Pissinati PSC. The meaning of care management attributed by nursing faculty members from the viewpoint of complex thinking. Rev Gaúcha Enferm[Internet]. 2016[cited 2017 Feb 04];37(3). Available from: http://www.scielo.br/pdf/rgenf/v37n3/0102-6933-rgenf-1983-144720160361097.pdf

5. Santos JLG, Pestana AL, Guerrero P, Meirelles BSH, Erdmann, AL. Nurses' practices in the nursing and health care management: integrative review. Rev Bras Enferm[Internet]. 2013[cited 2017 Feb 04];66(2):257-63. Available from: http://www.scielo.br/pdf/reben/v66n2/16.pdf 
6. Senna MH, Drago LC, Kirchner AR, Santos JLG, Erdmann AL, Andrade SR. Meanings of care management built throughout nurses' professional education. Rev Rene[Internet]. 2014[cited 2017 Feb 06];15(2):196-205. Available from: http://www.revistarene.ufc. br/revista/index.php/revista/article/view/1463/pdf_1

7. Hayshida KY, Bernardes A, Maziero VG, Gabriel CS. Decision-making of the nursing team after the revitalization of a decentralized management model. Texto Contexto Enferm[Internet]. 2014[cited 2017 Feb 06];23(2):286-93. Available from: http://www.scielo. $\mathrm{br} / \mathrm{pdf} / \mathrm{tce} / \mathrm{v} 23 \mathrm{n} 2 / 0104-0707-t c e-23-02-00286 . p d f$

8. Zanetti ML. Advanced nursing practice: strategies for training and knowledge building. Rev Latino-Am Enfermagem[Internet]. 2015[cited 2017 Feb 06];23(5):779-80. Available from: http://www.scielo.br/pdf/rlae/v23n5/0104-1169-rlae-23-05-00779.pdf

9. Nurse Practitioner/Advanced Practice Nurse: definition and characteristics. Nursing Matters[Internet]. 2009 [cited 2017 Feb 03]. Available from: https://acnp.org.au/sites/default/files/33/definition_of_apn-np.pdf

10. García PR, Vián OH, Hernández ASO, Alonso AIR, Jiménez MT. Enfermería de práctica avanzada: historia y definición. Enferm Clín[Internet]. 2002[cited 2017 Feb 03];12(6):286-9. Available from: http://www.elsevier.es/es-revista-enfermeria-clinica-35-pdf-S1130862102737674-S300

11. Barrio-Linares M. Competencias y perfil profesional de la enfermera de práctica avanzada. Enferm Intens[Internet]. 2014[cited 2017 Feb 03];25(2):52-57. Available from: http://www.elsevier.es/es-revista-enfermeria-intensiva-142-linkresolver-competenciasperfil-profesional-enfermera-practica-S1130239913000928

12. McMillan M, Bellchambers H. Nursing prescribing: adding value to the consumer experience. Aust Prescr[Internet] 2007[cited 2017 Feb 01];30(3):2-3. Available from: https://www.nps.org.au/australian-prescriber/articles/nurse-prescribing-adding-value-to-the-consumer-experience

13. Martin-Misener R, Bryant-Lukosius D, Harbman P, Donald F, Kaasalainen S, Carter N, et al. Education of advanced practice nurses in Canada. Nurs Leadership[Internet]. 2010[cited 2017 Feb 01];23(Spec):61-84. Available from: https://www.ncbi.nlm.nih.gov/pubmed/21478687

14. Fukuda H, Miyauchi S, Tonai M, Ono M, Magilvy JK, Murashima S. The first nurse practitioner graduate programme in Japan. Int Nurs Rev[Internet]. 2014[cited 2017 Apr 17];61(4):487-90. Available from: https:/www.ncbi.nlm.nih.gov/pmc/articles/PMC4277332/

15. Toso BRGO, Filippon J, Giovanella L. Nurses' performance on primary care in the National Health Service in England. Rev Bras Enferm[Internet]. 2016[cited 2017 Feb 01];69(1):169-77. Available from: http://www.scielo.br/pdf/reben/v69n1/en_0034-7167reben-69-01-0182.pdf

16. Horrocks S, Anderson A, Salisbury C. Systematic review of whether nurse practitioners working in primary care can provide equivalent care to doctors. BM][Internet]. 2002[cited 2017 Feb 01];6(324):819-23. Available from: http://www.bmj.com/content/bmj/324/7341/819.full.pdf

17. Newhouse RP, Stanik-Hutt J, White KM, Johantgen M, Bass EB, Zangaro G, et al. Advanced practice nurse outcomes 1990-2008: a systematic review. Nurs Econ[Internet]. 2011[cited 2017 Feb 03];29(5):230-50. Available from: https://www.ncbi.nlm.nih.gov/pubmedhealth/ PMH0048021/?report= reader

18. Toso BRGO. Práticas avançadas de enfermagem em atenção primária: estratégias para implantação no Brasil. Enferm Foco[Internet]. 2016[cited 2017 Feb 03];7(3/4):36-40. Available from: http://revista.portalcofen.gov.br/index.php/enfermagem/article/view/913/343

19. Conselho Federal de Enfermagem - COFEN. Enfermagem pactua implementação de práticas avançadas no Brasil[Internet]. 2016[cited 2017 Feb 03]. Available from: http://www.cofen.gov.br/enfermagem-pactua-implementacao-de-praticas-avancadas-no-brasil_40163.html

20. Brasil. Ministério da Educação. Portaria n 389 de 23 de março de 2017 - Dispõe sobre o mestrado e doutorado profissional no âmbito da pósgraduação stricto sensu[Internet]. 2017[cited 2017 May 30]. Available from: http://abmes.org.br/arquivos/legislacoes/Port-MEC-389-2017-03-23.pdf

21. Borges F, Marques LGS, Bugs TV, Tonini NS, Vasconcelos RO, Oliveira JLC. Competências gerenciais do enfermeiro coordenador em unidades de clínica médica e cirúrgica. Nursing. 2016; 19(220):1376-80.

22. Martiniano CS, Andrade OS, Magalhães FC, Souza FF, Clementino FS, Uchôa SAC. Legalization of nurse prescribing of medication in Brazil: history, trends and challenges. Texto Contexto Enferm[Internet]. 2015[cited 2017 Feb 03];24(3):809-17. Available from: http://www.scielo.br/ pdf/tce/v24n3/0104-0707-tce-24-03-00809.pdf 